\title{
The Use of Information Technology in Financial Management
}

\author{
Iryna Prikhno ${ }^{1 *}$, Valentyna Kuksa ${ }^{2}$, and Ivaylo Mihaylov ${ }^{3}$ \\ ${ }^{1}$ Cherkasy State Technological University, Finance Department, 460 Shevchenko Blvd., Cherkasy, 18006, Ukraine \\ ${ }^{2}$ Cherkasy Educational Scientific Institute University of Banking, Department of Management and Information Technologies, \\ 164 V. Chornovil Str., Cherkasy, 18028, Ukraine \\ ${ }^{3}$ Prof. Assen Zlatarov University, Department of Economics and Management, 1 Prof. Yakimov Str., 8010 Burgas, Bulgaria
}

\begin{abstract}
The article explores the concept of information technology and clarifies the essence of information technology in finance. The types of information technology in finance have been studied and their classification according to business entities has been carried out. A brief description of the main software products, the purpose of which is to ensure the implementation of the process of automation of financial research is given. The main tools for managing household (or person) finance using modern information technology are presented. The implementation of e-government in Ukraine is analyzed. The evaluation of the effectiveness of e-government implementation with the help of E-Government Development Index in Eastern European countries and in Ukraine is performed. A detailed analysis of the E-Government Development Index in Ukraine using a system of indicators has been studied. Digital technologies in the economy in general and in finance in particular have been studied separately. The indicators of world indexes digital economy development for Ukraine and for Eastern European countries are analyzed. The advantages and problems of the modern cryptocurrency market are clarified. The main directions of using artificial intelligence in finance are determine.
\end{abstract}

\section{Introduction}

The development of financial relations in the modern world requires the implementation of effective financial management in various spheres of human life.

Building an effective financial management system involves achieving this goal by performing certain tasks of organizational, informational, managerial, financial, legal, production, political, social types, and so on. This, in turn, is constantly influenced by external and internal factors, which together can have either negative or positive effects, accordingly, posing a danger (risks) for the realization of the goal or contributing to its achievement. Thus, the financial management requires the processing of a large amount of information, based on which the choice of the particular scenario of behaviour is done.

Therefore, in order to improve managerial decisionmaking process in finance, in order to be able to be competitive and successful in the market, to increase profitability and efficiency, to be able to respond quickly to external factors and adapt and change according to modern requirements, it is necessary to use information technology.

\section{Related literature}

Problems with the use of information technology in management are highlighted in the scientific works of domestic and international researchers.

In particular, the study of information technology in enterprise management is highlighted in the works of the following scientists: T. Baranovska, P. Buryak, J. Champi, V. Denysyuk, M. Hamer, A. Kozyryev, O. Kryvokon, T. Lepeyko, I. Lukasevych, K. Malachevska, L. Melnyk, J. Nabatova, A. Onopko, O. Prysyazhnyuk, O. Pushkar, A. Romanov, M. Royik, A. Shchedrin, H. Tytarenko, V. Utkin, J. Zhyhalkevych and others.

It should be noted that J. Nabatova and K. Malchevska in their scientific works explore the theoretical foundations of automation of the process of analysis and forecasting of financial results of the enterprise, analyze examples of statistical programs and tools that make it possible to perform analysis. Also, these scientists argue that "automation of analysis significantly improves the quality and accuracy of the results, frees employees from long and routine work, as well as takes the management of financial results to a new level, as it contributes to more informed and effective business decisions" [1].

Information technology in public administration is discussed in the scientific works of the following scientists: K. Andersen, L. Bakayev, O. Bakayev, A. Bersutsky, J. Bersutsky, S. Bretschnayder, P. Drucker, V. Glushkov, R. Kalyuzhny, N. Krasnozhon, M. Lepa, Z. Pavlyshyn, V. Porohnya, T. Pysarevska, V. Sytnyk, M. Tatarchuk, E. Toffler, O. Tsarenko and others.

Thus, Z. Pavlyshyn notes that "using information technologies in public administration with the ability to find alternative ways to set data, perform the functions of collecting, storing, processing, transmitting and using knowledge, really increases the efficiency of public 
administration, which allows to find the necessary resources". He also notes the tendency to increase the number of government agencies that use information technology, and emphasizes that without the use of information technology is now impossible to compete in the world market [2].

The problem of the application of information technology in finance has been investigated by M. Bastrikov, E. Burtseva, N. Emelyanova, A. Gavrylenko, T. Gavrylko, O. Korystin, M. Kurkov, A. Kwilinski, X. Li, L. Melnyk, I. Semakin, N. Svyrydiuk, I. Tkachenko, V. Tkachenko, O. Tomashevsky, O. Shatunova, C.A. Wang and others. In their works, they often mentioned digital finance, in particular, the impact of cryptocurrency on micro and macro indicators [3]. The following scientists have studied the problems of digitalization of the economy in more detail: O. Bilyk, R. Bukht, A. Cheko, G. Chmeruk, A. Dobrynin, R. Hicks, G. Karcheva, J. Levitska, V. Lyashenko, R. Narishman, V. Panasyuk, N. Podolchak, M. Rudenko, A. Semenog, D. Tapscott, A. Tugu, L. Zakharchenko and others. In particular, N. Podolchak, O. Bilyk and J. Levytska analyze the current state of digitalization and the main problems that hinder the intensive development of the digital economy [4].

We believe that scientists have made an invaluable contribution to the development of research in the application of information technology in financial management, but, in our opinion, taking into consideration the current processes of informatization, digitalization and globalization, some questions need more detailed and in-depth study.

\section{The purpose of the research}

The purpose of the article is to understand the existing information technology in finance, to systematize it, to identify its positive and negative impact on functioning finance of an enterprise (business), a household (person) and a state.

\section{Methods}

The methodological basis of the study were the theoretical provisions set out in the works of domestic and foreign authors. The methods of scientific abstraction and system analysis were used in the work.

\section{Results}

According to the Law of Ukraine "On the National Informatization Program", information technology is a purposeful organized set of information processes using computer technology that provides high speed data processing, fast information retrieval, data dissemination, access to information sources regardless of their location [5].

Note that along with the term "information technology", the term "information and communication technology" is widely used. Moreover, these two terms are often used as synonyms in scientific works. In our opinion, "information and communication technologies" is a more general term, which consists of information technology and telecommunications, media broadcasts, all types of audio and video processing and transmission of information.

Information technologies are implemented using IT tools - software (programming languages, operating systems, applications, etc.) and special equipment that allows you to process, transmit and store information (computers and computer equipment, modern communications, etc.).

Information technology of management processes refers to the methods and ways of interaction of the control and managed systems of the organization on the basis of use the modern tools for information transformation [2].

Based on the above definitions, it can be stated that information technology in financial management is the use of modern tools for the transformation of financial information or information necessary to make an effective financial decision.

Due to the availability of different entities of financial use, information technology in financial management should be divided into information technology in financial management of the enterprise (business), information technology in financial management of the household (person), information technology in state financial management of banking, budget, money and other systems. Also, given the rapid development of digital technologies and artificial intelligence, it is advisable to present separately the use of digital technologies in finance and the use of artificial intelligence in finance (Fig. 1).

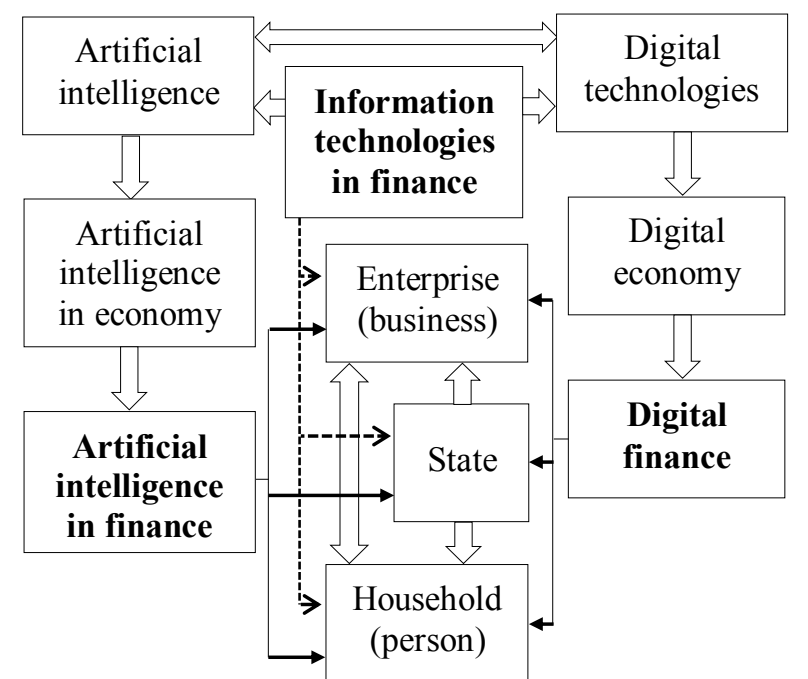

Fig. 1. Structuring the using of information technology in finance.

Source: authors' own development.

Taking into consideration the global trend of rapid development of information technology and digitalization, globalization and internationalization, the use of information technology in financial management of the enterprise (business) is one of the most important 
stages in the management of any enterprise, as it allows you to perform a comprehensive study of key financial indicators of the enterprise and perform effective planning and forecasting of its financial activity. The process of finding financial and analytical information and its research is quite extensive and time consuming, requires the involvement of a large number of specialists and a significant amount of various calculations, including and using methods of economic and mathematical programming and forecasting. That is why the automation of financial analysis processes has become natural and necessary, and it turned out to be possible due to the rapid development of information and digital technologies. Automation of financial analysis of the enterprise allows you to accelerate the process of evaluation of financial indicators, quickly and in the shortest possible time to identify possible risks and threats and plan further actions to minimize losses and increase profitability, allows you to identify potential domestic and foreign partners, suppliers, creditors, investors, etc. and to study the competitor activity and identify the most favorable markets in Ukraine and abroad.

The main advantages of automation of indicators of financial activity of the enterprise should include:

1) increase in productivity of financial managers: automation of calculations allows you to accelerate process of calculations and to release additional time for comprehension and evaluation of the obtained indicators and search and substantiation of alternative solutions to complex financial problems;

2) increasing the scale of the study: automation of calculations allows you to perform calculations using a large amount of information and a significant number of indicators, which indicate the possibility of a comprehensive study of the impact of all (or the vast majority) factors on enterprise financial indicators;

3) improving the quality of analysis: automation of calculations allows you to get more accurate and diagnostically reliable results of the analysis, which will help to prevent and eliminate errors and allow you to formulate conclusions and recommendations for more efficient operation of enterprise finance.

The main tool in ensuring the implementation of the process of automation of financial research is the software represented by various software products (programs, packages). The wide range of such software products presented on the market caused the need to systematize them according to the following criteria:

1. Depending on the functionality of the program for financial analysis [1]:

1.1. General purpose programs (universal programs):

STADIA is the universal statistical package, which is a set of modern methods of analysis: categorical, variance, correlation and spectral analysis, smoothing, filtering, forecasting, regression, discriminant, cluster and factor analysis, quality control methods, sequential analysis and replacement of missing data, and also contains a complete set of business and scientific graphics (functions, dependencies, maps, charts, etc.) [6];
STATGRAPHICS is a comprehensive Windows desktop product designed to perform statistical analysis, data visualization and forecasting with the help of more than 290 statistical operations, procedures and special functions [7];

IBM SPSS is a platform of statistical software that has the necessary set of functions for the analysis of its own financial, statistical, informative data. The obtained results are quite easy and clear to visualize, so the program is universal for users of different levels. SPSS offers two programs, SPSS Statistics, which is based on a top-to-bottom approach, and SPSS Modeler, which uses a bottom-up analysis [8];

STATISTICA is an universal package for comprehensive statistical analysis, which implements procedures for data analysis (data analysis), data management (data management), data mining (data mining), data visualization (data visualization). This program allows you to calculate descriptive statistics; analyze time series and predict, perform regression, discriminant, cluster, variance analysis, analysis of correspondences, etc. [9].

1.2. Professional programs:

SAS (Statistical Analysis System) is a program that provides the ability to analyze spreadsheets, perform statistical analysis, build forecasts, provides access to data, allows you to write reports. The program contains a significant number of built-in mathematical and financial functions, including depreciation, compound interest, cash flow, hyperbolic functions, factorials, combinations and mechanisms etc. [10].

1.3. Specialized programs:

MESOSAUR is a program, used for time series analysis (smoothing, filtering, autocorrelation, crosscorrelation, spectral, cross-spectral analysis), allows you to perform regression analysis, solve parametric and nonparametric problems $[1,11]$;

DATASCOPE is a statistical package that specializes in performing multidimensional data analysis. [1]:

2. Depending on the country that uses the program

\subsection{Used in foreign countries:}

EViews (Econometric Views) is a statistical package that allows you to analyze econometric data of time series, perform analysis and simulate and forecast data, build regression models using a modern, innovative and easy to use interface. This program is used in financial analysis, in macroeconomic forecasting, in modeling economic processes, in forecasting market indicators, etc. [12];

Maple (Waterloo Maple) is a computer program, which allows you with the help of built-in functions of modern mathematics (more than 5000 functions) to carry out modeling, interactive visualization, gives the chance to combine results of calculations, formulas, text files, graphic objects, sound effects in one electronic document [13];

$\mathrm{R}$ is both a programming language and a software environment that allows you to perform statistical calculations, perform analysis and display the results of calculations in graphical form $[1,14]$.

\subsection{Used in Ukraine:}




\section{Programs for analysis:}

MS Excel: This program is one of the MS Office programs and is currently the most widespread program in Ukraine. It is used for financial analysis of domestic enterprises. The Ukrainian market presents both readymade products developed in MS Excel, which can be used in enterprises as needed, and directly MS Excel is often used by financiers, economists, managers, accountants in enterprises for their own calculations. This program is a spreadsheet that contains ready-made built-in mathematical formulas, represented by a fairly powerful mathematical apparatus, and also allows you to create in the cells of the table needed to automate the calculation of the formula. Tables can be linked together, allowing you to process a large amount of information while using many metrics. In this program regression analysis can be performed, predictive calculations can be made, sorted, highlighted, various graphical objects can be built. MS Excel also contains a built-in programming language Visual Basic for Applications (VBA), which allows you to create algorithms for calculating certain indicators. All tables and graphical objects created in MS Excel are easily transferred to any other office program MS Office, which, of course, facilitates the process of further work with the obtained results of the analysis (writing a report, sharing files or their separate parts, etc.).

Google Sheets, Google Apps Script, Google Analytics are programs offered by Google and are free web software packages designed to perform financial analysis. Google Sheets is a spreadsheet program using powerful financial analysis tools, which is based on the use of artificial intelligence technologies, which, accordingly, allows you to get fairly accurate calculations and predict balanced directions for solving problems. Google Apps Script - with this program it is possible to create macros, which simplifies the process of financial calculations and automate the process of preparing and writing reports. Google Analytics is a program designed to perform web analytics on the Internet: it analyzes Internet sites and mobile applications [3].

\section{Reporting Programs:}

"1C: Enterprise" is a series of programs that belong to one platform and are represented by different products depending on the needs and specifics of the business. This program allows you to automate the accounting of enterprises in different areas of activity, different forms of ownership, different scales and more. "1C: Enterprise" offers the following programs:

a) " $1 \mathrm{C}$ : Accounting" is automation of accounting and tax accounting in organizations related to any type of business. The program allows to carry out: accounting of standard operations, accounting of inventories, warehouse accounting, accounting of trade operations, accounting of commission trade, accounting of operations with container, accounting of bank and cash operations, accounting of settlements with counterparties, accounting of fixed assets, intangible and low-value assets, accounting for primary and secondary production, accounting for semi-finished products, accounting for indirect costs, VAT accounting, payroll accounting and personnel accounting. Also, the program "1C: Accounting" supports various tax schemes, allows you to carry out the final operations of the month, generate standard accounting reports, create regulated reporting, keep records of activities of several organizations, to carry out tax accounting for income tax and single tax;

b) " $1 \mathrm{C}$ : Commercial Enterprise Management" is automation of management and accounting tasks at enterprises engaged in any type of commercial activity;

c) "1C: Manufacturing Enterprise Management" is automation of management and accounting at the manufacturing enterprise;

d) "1C: Salary and Personnel Management" is a tool for the implementation of personnel policy of the enterprise, as well as the automation of various services of the enterprise, ranging from personnel management and line managers to accounting staff. The program " $1 \mathrm{C}$ : Salary and personnel management" allows: to keep records of activities of several organizations, to plan staffing needs, automate recruitment, to manage competencies and financial motivation of employees, to plan staffing, personnel accounting and personnel analysis, to regulate labor relations and to keep personnel records, to carry out calculation and accounting of wages and deductions of regulated taxes, to compile regulated reporting;

e) "1C: Small Business Management" is automation of operational management in small businesses;

f) " $1 \mathrm{C}$ : CRM" is automation of customer relationship processes; helps to organize effective work of departments of sales, marketing, service at all stages of interaction with customers [15];

BAS is a line of programs that allow you to automatically perform a wide range of tasks related to the management of the enterprise in various aspects. The main programs of BAS are: Accounting, Accounting CORP, Integrated Enterprise Management, Document Management CORP, Small Business, Retail, Trade Management, Holding Management, ERP (financial management, including accounting for deposits and loans, acquiring (payment cards), flexible instruments) for maintaining a payment calendar, expanded capabilities for managing current payments, routes for reconciling applications, flexible tools for generating payment documents for future dates, inventory of cash registers and bank accounts, analytical reporting on cash flows, chart of accounts for international financial accounting, translation of transactions into the IFRS subsystem data of operative and regulated accounting, deferred display of postings in the account, creation of documents on standard operations, audit, the generator of financial reports) [15].

Note that "1C: Enterprise" and its software products are still the most widely used in Ukraine. However, it should be noted that BAS products are increasingly being developed and implemented in domestic enterprises, as they offer a number of programs that are similar to the programs offered by "1C: Enterprise", but more adapted to modern requirements, have an updated interface, which is more user-friendly, expand the user's ability to customize the program according to his needs. 
Therefore, we can predict that there is a high probability that over time, new BAS products will compete and take a worthy place next to $1 \mathrm{C}$ or even replace 1C.

Programs for Information Exchange and Reporting:

FlyDoc is a special program, the purpose of which is the rapid exchange of documents in electronic form. This program is installed directly in the program " $1 \mathrm{C}$ : Enterprise". The transmitted information is available only to the sender and recipient [15].

M.E.Doc is a program that allows to carry out electronic document management (reports, agreements, tax invoices, acts, invoices and other documents). With the help of this program you can create tax invoices and sign them with an electronic digital signature, register them in the Unified Register of Tax Invoices, receive receipts in return or necessary extracts from the register, exchange registered tax invoices with receipts for their registration with counterparties. The M.E.Doc program allows sending electronic reports to the State Tax Inspectorates, the State Statistics Service, the Pension Fund, the State Employment Center, and the Social Insurance Fund. In order to meet the needs of different business entities, the following software products are offered: Reporting, Reporting to the NBU for nonbanking institutions, Electronic document management, VAT accounting, Excise and TTN, Salary, ARI "Cashalot" (registration of electronic checks in the State Tax Service), "SOTA" (online reporting) [15].

Information technology in household (person) financial management is associated with the emergence of modern programs, the purpose of which is to help in the efficient distribution of income and expenses. Currently, users are offered the following programs: "Home Accounting", Moneytracker, Personal Finances, "Your Money", MyBudget, IControlMyMoney, iCASH, Electronic System "All PRO Money", "DomEconom", "AbilityCash", "Buddi" and others. As you can see, in the modern world there are a significant number of tools for managing household finance (a person) using modern information technology, which is presented in the form of computer programs, mobile applications, online financial control tools.

At the state level, in the context of the development of modern information technology, the evaluation of the implementation of e-government in Ukraine deserves attention.

According to the Concept of e-government development in Ukraine, e-government is a form of public administration that promotes efficiency, openness and transparency of public authorities and local governments with the use of information and telecommunications technology to form a new type of state focused on meeting the needs of citizens [16].

This Concept defines comprehensive measures aimed at:

- modernization of public services and development of interaction between government, citizens and business through information and communications technology (development of electronic services, development of open data, development of electronic tools for involving citizens, development of electronic identification and trust services);
- modernization of public administration with the help of information and communications technology (development of electronic interaction, development of electronic document management, e-government in basic industries and support of priority reforms);

- e-government development management (formation of basic information and telecommunications infrastructure of e-government, increase of efficiency of e-government development management) [16].

There are the following levels of implementation of e-government:

G2C (government to citizens) is organization of feedback with citizens;

G2E (government to employees) is the relationship of government with officials or employees);

G2B (government to business) is the relationship between government agencies and business;

G2G (government to government) is automation of relations and document flow between departments [17].

The effectiveness of e-government implementation can be assessed using the E-Government Development Index (EGDI), which is an aggregate indicator based on three indices that reflect:

1) the level of development of online services (Online Service Index);

2) the level of development of telecommunications infrastructure (Telecommunications Infrastructure Index);

3) the level of human development (Human Capital Index).

Listed in Table 1 statistics of E-Government Development Index in Eastern European countries show that during 2014-2020 the implementation of egovernment developed quite rapidly: the meaning of this Index increased on average from $0.50-0.66$ to $0.71-0.85$.

Table 1. Analysis of E-Government Development Index in Eastern European Countries in 2014-2020.

\begin{tabular}{|l|c|c|c|}
\hline \multicolumn{1}{|c|}{ Country } & $\mathbf{2 0 1 4}$ & $\mathbf{2 0 2 0}$ & Growth \\
\hline Ukraine & 0.5032 & 0.7119 & +0.2087 \\
\hline Bulgaria & 0.5421 & 0.7980 & +0.2559 \\
\hline Czech Republic & 0.6070 & 0.8135 & +0.2065 \\
\hline Hungary & 0.6637 & 0.7745 & +0.1108 \\
\hline Poland & 0.6482 & 0.8531 & +0.2049 \\
\hline Slovak Republic & 0.6148 & 0.7817 & +0.1669 \\
\hline
\end{tabular}

Source: developed by the authors according to the source [18, 19].

Note that the meaning of this Index in Ukraine was lower compared to other studied Indexes in Eastern European countries: 0.5032 in 2014 and 0.7119 in 2020. In Bulgaria this Index changed from 0.5421 in 2014 to 0.7119 in 2020. The highest E-Government Development Index was in Poland in $2020-0.8531$. Although it is worth noting that the largest increase during the studied period was recorded in Bulgaria $(+0.2559)$ and Ukraine $(+0.2087)$. 
Detailed analysis of E-Government Development Index in Ukraine and Bulgaria in 2020 (Fig. 2) showed that the level of human development in Ukraine was quite high (Human Capital Index was 0.8591 in Ukraine and 0.8401 in Bulgaria), the level of development of online services was above the middle (Online Service Index was 0.6824 in Ukraine and 0.7706 in Bulgaria), and the level of development of telecommunications infrastructure was above the middle (Telecommunication Infrastructure Index was 0.5942 in Ukraine and 0.7826 in Bulgaria). The results of the analysis showed that in Ukraine and Bulgaria it is necessary to continue working on the development of e-government.

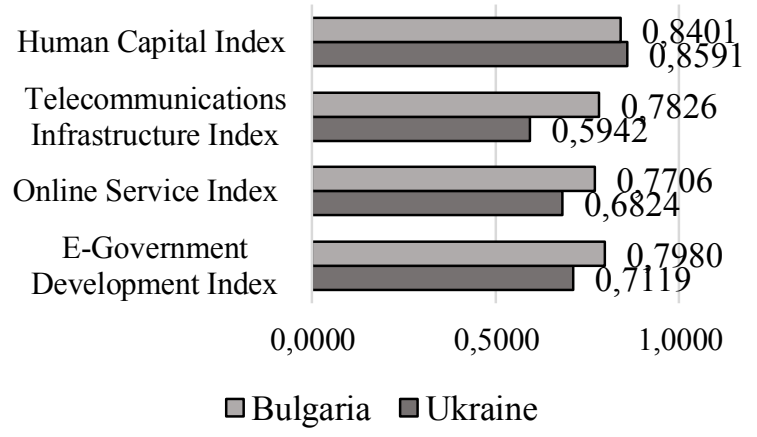

Fig. 2. Detailed Analysis of E-Government Development Index in Ukraine in 2020.

Source: developed by the authors according to the source [19].

Thus, in the context of strengthening the innovative development of information technology, the formation of an effective e-government system should continue not only with the support of public authorities, but also with the assistance of all stakeholders, as only joint efforts can ensure effective interaction of state and regional structures, as well as local governments with business (enterprises) and the person (households).

Information technology in state financial management is primarily represented by the System of Electronic Payments (SEP), which provides $96 \%$ of interbank transfers in the national currency within Ukraine. As of the end of 2019, 75 banks of Ukraine, the State Treasury Service of Ukraine and the National Bank of Ukraine were SEP participants [20].

The efficiency of the SEP in Ukraine is evidenced by the annual increase in the amount and number of payments processed in the SEP (Fig. 3).

During 2015-2019, the number of payments processed in the SEP increased by 85 million units (by $28.4 \%$ ), and the total amount of payments increased by UAH 14 trillion (by $77.8 \%$ ). In 2019, the SEP processed 384 million payments totaling UAH 32 trillion.

In today's world, information technology is closely linked to digital technology, which has recently become increasingly active in all areas of human life, including and the economy. The mechanism of digital technology is the encoding of information and its transmission, which contributes to a significant number of operations in a short period of time. The main tools for the application of digital technologies today are the Internet and mobile phones (smartphones), computers, laptops, tablets. Since these devices are widespread and widely used by a large number of people in all spheres of life, so the rapid development of the digital economy is natural.

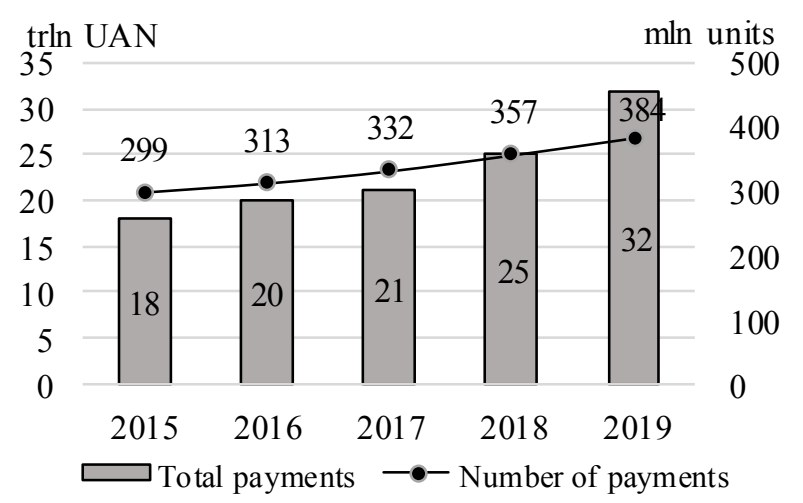

Fig. 3. Analysis of Payments processed in the SEP in Ukraine in 2015-2019.

Source: developed by the authors according to the source [20].

Today, the part of the traditional economy is declining and the part of the digital economy is growing around the world. In European countries, the process of digitization (digitalization) began in 2010, when the European Commission decided to create a Digital Single Market [21].

In Ukraine, for the first time the development of the digital economy at the state level, taking into account the European integration course of our country, was announced in 2016, when the Ministry of Economic Development and Trade of Ukraine developed a project "Digital Agenda of Ukraine - 2020", which defined the conceptual principles of digital economy implementation [22]. Also in 2018, the Cabinet of Ministers of Ukraine approved the "Concept for the development of digital economy and society of Ukraine for 2018-2020", which provided for the implementation of measures to implement appropriate incentives for digitalization of the economy, public and social spheres, awareness of existing challenges and tools for digital infrastructure development, acquisition of digital competencies by citizens, as well as identified critical areas and projects of digitalization, stimulation of the internal market of manufacturing, use and consumption of digital technologies [23].

According to this Concept, digitalization means the saturation of the physical world with electronic-digital devices, tools, systems and the establishment of electronic-communication exchange between them, which actually allows the integrated interaction of virtual and physical, that is, it creates cyberspace.

The Concept also identified the main goals of digital development, in particular: accelerating economic growth and attracting investment; transformation of economic sectors into competitive and efficient; technological and digital modernization of industry and creation of high-tech industries; accessibility of the benefits and opportunities of the digital world for 
citizens; realization of human resources, development of digital industries and digital entrepreneurship.

The Concept provided a plan to reach a certain level in the world rankings for the development of the digital economy. Thus, in 2020 Ukraine had to occupy:

30th place in the Networked Readiness Index (WEF)

(in 2016, Ukraine ranked 64th place);

40th place in the Global Innovation Index (INSEAD, WIPO) (in 2016 - 56th place);

50th place in the ICT Development Index (ITU) (in 2016 - 79th place);

60th place in the Global Competitiveness Index (WEF) (in 2016 - 85th place) [23].

The effectiveness of the implementation of this Concept can be assessed by analyzing the global indexes of digital economy, which were officially published in 2016-2019 (Table 2) [24-27].

Table 2. Indicators of the world indexes of digital economy development in Ukraine in 2016-2019.

\begin{tabular}{|l|c|c|c|c|}
\hline \multicolumn{1}{|c|}{ Index name } & $\mathbf{2 0 1 6}$ & $\mathbf{2 0 1 7}$ & $\mathbf{2 0 1 8}$ & $\mathbf{2 0 1 9}$ \\
\hline $\begin{array}{l}\text { The IMD World Digital } \\
\text { Competitiveness Ranking }\end{array}$ & 59 & 60 & 59 & 54 \\
\hline Global Connectivity Index & 55 & 55 & 54 & 50 \\
\hline Global Innovation Index & 56 & 50 & 43 & 47 \\
\hline $\begin{array}{l}\text { Global Competitiveness } \\
\text { Index }\end{array}$ & 85 & 81 & 83 & 85 \\
\hline
\end{tabular}

Source: developed by the authors according to the source [2427].

These indexes indicate that Ukraine occupies a rather low position in world indexes and ratings of the digital economy, and the indicators planned in the Concept as of the end of 2019 have not been achieved.

Note that in Ukraine, however, there are positive trends towards the digitalization of the economy, as almost all of the studied world indexes in our country its position has been improved in the global rankings. Note that in 2019, according to the Global Connectivity Index, Ukraine ranked 50th compared to 55th in 2016; and in the IMD World Digital Competitiveness Ranking, Ukraine ranked 54th, which is 5 positions higher than in 2016. According to the Global Innovation Index and the Global Competitiveness Index, Ukraine improved its position during 2016-2018, and in 2019 there was there letdown of position.

Comparing the world indexes of digital economy development in Eastern European countries, it is worth noting that Ukraine shows the lowest result (Fig. 4) [2427].

Special attention needs to be paid to the study of the financial component of the digital economy (so-called "digital finance"). The point is that modern information technology can significantly change the traditional forms of money, gradually turning them into so-called cryptocurrency.

Note that cryptocurrency is a new experimental type of money that works in a distributed and decentralized system of secure exchange and transfer of digital banknotes based on cryptography [28].

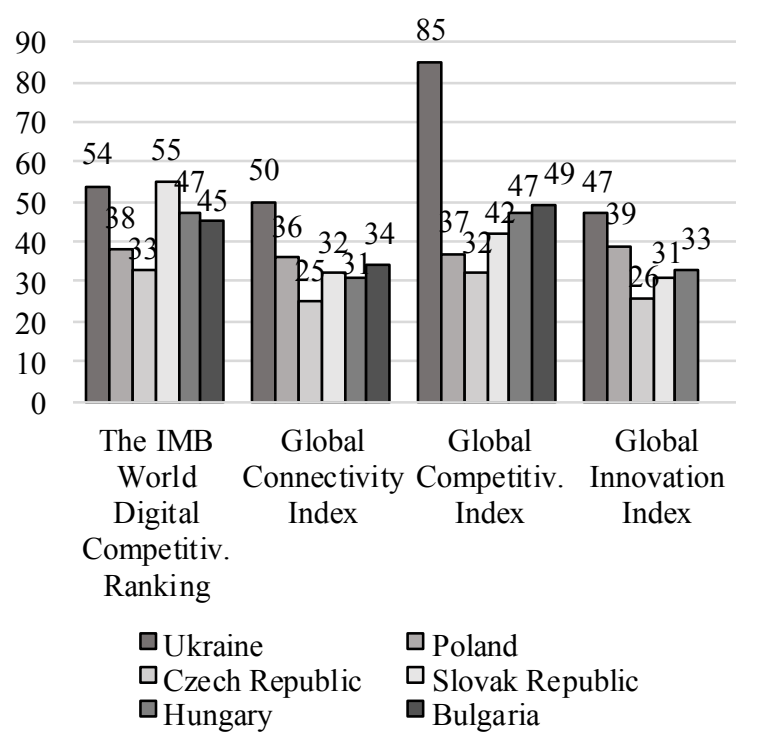

Fig. 4. Comparison of the world indexes of digital economy development in Eastern European countries in 2019.

Source: developed by the authors according to the source [2427].

Cryptocurrency is a currency that exists in the form of digital money, has no material content and exists in circulation on the Internet, is independent of the central bank.

Cryptocurrency is a currency that exists in the form of digital money, has no material content and exists in circulation on the Internet, is independent of the central bank.

Historically, the first cryptocurrency was bitcoin (BTC), which was introduced in January 2009 [3]. In a relatively short period of time (only 12 years) the number of types of cryptocurrency has increased to 1009 , but the leading position is retained by bitcoin [29].

The vast majority of cryptocurrencies have an insignificant market capitalization and a low price. Only 16 cryptocurrencies today have the market capitalization of over USD 1 billion (Table 3).

Bitcoin remains the main cryptocurrency today, as well as during the whole period of cryptocurrency operation. The number of existing bitcoins is more than 18.6 million with a total market capitalization of over USD 610.1 billion. In January 2021, the price of one bitcoin was about USD 32.8 thousand.

Ethereum ranks second in the ranking of cryptocurrencies in the world. The number of all existing ethereums now amounts to about 114.4 million, with a total capitalization of over USD 153.3 billion. In January 2021 , the cost of one ethereum was USD 1.3 thousand [29].

As you can see, the use of cryptocurrencies has gained significant momentum, but still a number of issues remain open and need to be refined. 
Table 3. Analysis of the top cryptocurrencies on January 25, 2021.

\begin{tabular}{|l|c|c|}
\hline \multicolumn{1}{|c|}{ Cryptocurrency } & $\begin{array}{c}\text { Market } \\
\text { capitalization } \\
\text { in USD }\end{array}$ & $\begin{array}{c}\text { Price } \\
\text { in USD }\end{array}$ \\
\hline Bitcoin (BTC) & 610146914252 & 32787,74 \\
\hline Ethereum (ETH) & 153351822186 & 1340,69 \\
\hline XRP (XRP) & 12180662400 & 0,276 \\
\hline Cardano (ADA) & 11441229292 & 0,368 \\
\hline Litecoin (LTC) & 9454248196 & 141,41 \\
\hline Bitcoin Cash (BCH) & 8320149169 & 446,76 \\
\hline Stellar Lumens (XLM) & 6229823631 & 0,282 \\
\hline Bitcoin SV (BSV) & 3278703930 & 176,08 \\
\hline EOS (EOS) & 2828438984 & 2,76 \\
\hline Monero (XMR) & 2534726108 & 142,23 \\
\hline Tezos (XTZ) & 2451237393 & 3,23 \\
\hline TRON (TRX) & 2186433125 & 0,031 \\
\hline IOTA (IOT) & 1301877853 & 0,468 \\
\hline Dogecoin (DOGE) & 1135127851 & 0,0089 \\
\hline Zcash (ZEC) & 1100458032 & 90,61 \\
\hline Dash (DASH) & 1095716842 & 110,24 \\
\hline Source: developed by the &
\end{tabular}

Source: developed by the authors according to the source [29].

For example, the issue of anonymity of transactions in the bitcoin system remains controversial. The system has a public register of all transactions that have taken place throughout the history of this cryptocurrency. However, it should be noted that the real names of the participants are not displayed during transactions in the blockchain, but are indicated by user aliases. On the one hand, this allows you to protect the personal data of the e-wallet owner at the same time as an open transaction history. On the other hand, the lack of identification of a person, as in the case of traditional methods of monetary currency transactions, can have negative consequences associated with the possibility of avoiding liability in the case of illegal transactions [3].

Another problem is the legal inregulation of the status and circulation of cryptocurrencies. Thus, legal entities do not have the opportunity to use cryptocurrency, as they cannot include it in the charter and use it as an asset of the enterprise. We believe that theoretically enterprises could have a positive effect from the use of cryptocurrency, as cryptocurrency transactions save significant amount of time and labor, and there is no commission, so enterprises have the opportunity to save money and use them in production.

It should be noted that at the beginning of December 2020 the Verkhovna Rada of Ukraine adopted at the first reading the draft law "On Virtual Assets" [30]. The issue of adopting this Law is debatable. The drafters of the bill believe that the adoption of the Law will regulate legal relations regarding the circulation, storage, possession, use and conduct of transactions using cryptocurrency in Ukraine. Instead, experts, mostly agreeing with the need to legalize cryptocurrency, believe that some provisions need serious refinement. This Law does not define specific mechanisms and procedures with virtual assets, but only allows their use. In addition, although cryptocurrency acquires legal status, but it is not recognized as a means of payment, that was the main idea of creating bitcoin.

The disadvantages of using cryptocurrencies should also include the risk of significant market price fluctuations, which does not depend on the market capitalization of cryptocurrency (one of the characteristics of cryptocurrency is its high volatility). Therefore, it is difficult to predict exactly how the exchange rate of any cryptocurrency will behave in the market, and the owner of a cryptocurrency wallet has no guarantees that it will be saved.

However, the demand for cryptocurrency is appreciable, so in the future this market will continue to develop and improve.

Artificial intelligence as a separate direction of information technology development is developing more and more every year. Thus, in 2017, the market for artificial intelligence was about USD 2.42 billion, in 2021 is projected to grow to USD 16.2 billion, and in 2023 - about USD 34.4 billion [31].

Artificial intelligence is a branch of computer science that studies the processes of automating intelligent behavior.

Note that in Ukraine at the end of 2020 the Concept of Artificial Intelligence Development in Ukraine was approved, which defines that artificial intelligence is one of the priority areas in scientific and technological research, outlines the problems of state policy for artificial intelligence and identifies areas for solving them [32].

Artificial intelligence allows you to simultaneously process huge amounts of information and get the best solutions to the problem.

The financial sector is one of the most adapted to the use of artificial intelligence compared to other sectors.

Based on the analysis of domestic and foreign literature $[33,34]$, the following areas of application of artificial intelligence in finance were identified:

1. Trading, Wealth Management, and Investment Banking - the use of software for natural language processing (natural language processing NLP), which allows you to collect and analyze information about the state of foreign exchange markets, provide forecasts for the market conditions, provide investors with information on what shares to buy and sell for their customers, assess the various risks. The use of "roboadvisors" (or the digital advice market) allows you to effectively manage investments.

2. Digitizing Paper Documents - artificial intelligence programs help digitize paper documents. This is a necessary condition for the further use of artificial intelligence, the action of which is based on numbers.

3. Searching Through Large Databases of Documents - artificial intelligence programs help to search in the institution's own huge repositories of digital documents, sort this information, organize it. 
4. Underwriting - artificial intelligence programs allow banks and insurance companies to find information about the applicant's public activities (for example, their publications on social networks), on the basis of which a conclusion is made about its reliability.

5. Credit score - such artificial intelligence programs can calculate credit scores of customers, using not only the past credit history of customers, but also other characteristics.

6. Credit risk management in portfolios - the use of artificial intelligence allows you to calculate credit risks, which take into account a significant number of macrofinancial factors.

7. Chatbots - the use of chatbots allows you to inform about products and services, provide contact information, financial recommendations to the client, make payment transactions, show exchange rates and exchange currency, keep track of personal finances, transfer from card to card, send orders for trade and online acquiring and checking the counterparty.

8. Personal virtual assistant - is a program that allows you to answer customer questions on financial and banking issues like the financial advisors.

9. Training of bank employees - on the basis of artificial intelligence analysis of the conversation of the bank's specialist with the client and conclusions about the mistakes made by the bank employee and ways to correct them.

Thus, it can be noted that artificial intelligence has now established itself as a promising area of research, which is actively penetrating into various areas of human life, including and in the financial sphere.

It is worth noting that, in our opinion, the benefits of using artificial intelligence for some businesses in parallel have a negative impact for others. For example, a reduction in labor costs due to the use of artificial intelligence is a positive consequence for businesses and at the same time has a negative impact on the workforce, as jobs are reduced, unemployment rises, there is a need to improve skills or get a new education.

Another example is the increasing demand for mathematical and technical specialties in the field of artificial intelligence, which is undoubtedly positive for the workforce, but requires significant costs of the enterprise (business) to conduct research.

Thus, artificial intelligence initiates a new stage of the industrial revolution and in the future can radically change human life. It is important to understand that artificial intelligence deprives a person of the ability to think and make decisions, which can ultimately lead to a decrease in people's intellectual abilities. Therefore, introducing artificial intelligence in any field, including and financial, it is necessary to seriously weigh all the positive and negative consequences.

\section{Conclusions}

Summing up the results of the study, we note that today the use of information technology has reached a new stage of development, due to the rapid development of digital technologies. All countries of the world, including Ukraine and Bulgaria, faced a new challenge: the digitalization of all spheres of life. Significant steps in this direction have already been taken, but any innovation process is always accompanied by problems and shortcomings that need to be promptly eliminated.

We believe that in order to establish the effective functioning of information technology in finance, it is necessary to: 1) promote the creation of national information systems, platforms and technologies in order to reduce the share of foreign software; 2) organize and provide internships for information technology developers; 3) to carry out explanatory work and to organize trainings for the purpose of informing the population about advantages of application of information technologies; 4) stimulate enterprises to use information technology, including and finance; 5) to expand Internet coverage in Ukraine, in particular, in small settlements where there are no Internet communications, which will contribute to the expansion of information technology users.

We think that in order to establish the effective functioning of information technology in finance it is necessary to: 1) promote the creation of national information systems, platforms and technologies in order to reduce the share of foreign software; 2) organize and provide internships for information technology developers; 3) to carry out explanatory work and to organize trainings for the purpose of informing the population about advantages of application of information technologies; 4) stimulate enterprises to use information technology, including the finance; 5) to expand Internet coverage in Ukraine, in particular, in small settlements where there are no Internet communications, which will increase the number of users of information technology.

Therefore, in order to establish the effective functioning of all spheres of life with the use of digital technologies, it is necessary to continue working on finding improved rules for legislative regulation of the application of information technology in finance and create new methods of information technology management.

\section{References}

1. J. Nabatova, K. Malachevska, Avtomatyzatsiya analizu ta prohnozuvannya finansovykh rezul'tativ pidpryyemstva (Automation of analysis and forecasting of an enterprise's financial results). Efektyvna ekonomika. 12 (2020), http://www.economy.nayka.com.ua/?op=1\&z=8405. Accessed 25 Jan 2021. doi:10.32702/2307-21052020.12.80

2. Z. Pavlyshyn, Strukturno-funktsional'nyy analiz vykorystannya informatsiynykh tekhnolohiy i system u derzhavnomu upravlinni (Structural and functional analysis of the use of information technologies and systems in public administration). Efektyvnist' Derzhavnoho Upravlinnya. 3(48), vol. 1, 162-166 (2016)

3. V. Tkachenko, A. Kwilinski, O. Korystin, N. Svyrydiuk, I. Tkachenko, Assessment of 
information technologies influence on financial security of economy. Journal of Security and Sustainability. 8(3), 387-384 (2019), https://www.researchgate.net/publication/33199962 6_Assessment_of_information_technologies_influen ce_on_financial_security_of_economy. Accessed 25 Jan 2021

4. N. Podolchak, O. Bilyk, YA. Levytska, suchasnyy stan tsyfrovizatsiyi v Ukrayini (The condition of digitalization in Ukraine). Efektyvna ekonomika. 10 (2019), http://www.economy.nayka.com.ua/pdf/ 10 2019/6.pdf. Accessed 25 Jan 2021. doi: 10.32702/2307-2105-2019.10.4

5. Pro Natsional'nu prohramu informatyzatsiyi (On the National Informatization Program), Law of Ukraine, 4 Feb 1998 No 74/98-BP. Verkhovna Rada of Ukraine. https://zakon.rada.gov.ua/laws/ show/74/98-\%D0\%B2\%D1\%80\#Text. Accessed 25 Jan 2021

6. Universal'nyy statystychnyy paket STADIA 8.0 (Universal statistical package STADIA 8.0). Allsoft Ukrayina, https://allsoft.prom.ua/p387839347universalnyj-statisticheskij-paket.html. Accessed 25 Jan 2021

7. Statgraphics Technologies, Inc. CoreWin, https://corewin.com.ua/statgraphics. Accessed 25 Jan 2021

8. IBM SPSS software. IBM, https://www.ibm.com/analytics/spss-statisticssoftware._Accessed 25 Jan 2021

9. V.S. Fetisov, Paket statystychnoho analizu danykh STATISTICA (Package of statistical data analysis STATISTICA). (Nizhyn Mykola Gogol State University, Nizhyn, 2018), p. 114

10. Try SAS for Free. SAS, https://www.sas.com/en_us/home.html. Accessed 25 Jan 2021

11. M. Royik, O. Prysyazhnyuk, V. Denysyuk, Ohlyad prohramnykh zasobiv statystychnoho analizu danykh (Review of software for statistical data analysis). Efektyvna ekonomika. 7 (2017), http://www.economy.nayka.com.ua/?op=1\&z=5676. Accessed 25 Jan 2021

12. What is EViews? EViews, https://www.eviews.com/home.html. Accessed 25 Jan 2021

13. Maplesoft Product Line. Maplesoft, https://www.maplesoft.com/products. Accessed 25 Jan 2021

14. What is R? The R Foundation, https://www.rproject.org/about.html. Accessed 25 Jan 2021

15. SOFTCOM, https://www.softcom.ua/ua/1c/v8. Accessed 25 Jan 2021

16. Kontseptsiya rozvytku elektronnoho uryaduvannya $v$ Ukrayini (Concept development of e-government in Ukraine), Order of the Cabinet of Ministers of Ukraine, 20 Sep 2017 No 649-p. Verkhovna Rada of Ukraine. https://zakon.rada.gov.ua/laws/show/ 6492017-\%D1\%80\#Text. Accessed 25 Jan 2021

17. O. Tsarenko, N. Krasnozhon, Elektronne uryaduvannya yak instrument posylennya konkurentospromozhnosti krayiny (E-government as a tool for strengthening the country's competitiveness). Efektyvna ekonomika. 8 (2017), http://www.economy.nayka.com.ua/?op=1\&z=8123. Accessed 25 Jan 2021. doi: 10.32702/2307-21052020.8.74

18. United Nations e-government survey 2014 (UNITED NATIONS, New York, 2014), https://publicadministration.un.org/egovkb/Portals/e govkb/Documents/un/2014-Survey/E-Gov Complete_Survey-2014.pdf. Accessed 25 Jan 2021

19. United Nations e-government survey 2020 (UNITED NATIONS, New York, 2020), https://publicadministration.un.org/egovkb/Portals/e govkb/Documents/un/2020-Survey/2020\%20UN $\% 20$ E-Government $\% 20$ Survey $\% 20$ (Full $\% 20$ Report).pdf. Accessed 25 Jan 2021

20. Zvit z oversayta infrastruktur finansovoho rynku za 2019 rik (Report on the oversight of financial market infrastructures for 2019). National Bank of Ukraine. 35 p. https://bank.gov.ua/admin_uploads/ article/Report_oversight_2019.pdf?v=4. Accessed 25 Jan 2021

21. EU Digital Single Market. https://eufordigital.eu/discover-eu/eu-digital-singlemarket. Accessed 25 Jan 2021

22. Tsyfrova adzhenda Ukrayiny - 2020 (Digital agenda of Ukraine-2020). HITECH office. 2016. 90 p. https:/ucci.org.ua/uploads/files/58e78ee3c 3922.pdf. Accessed 25 Jan 2021

23. Pro skhvalennya Kontseptsiyi rozvytku tsyfrovoyi ekonomiky ta suspil'stva Ukrayiny na 2018-2020 roky ta zatverdzhennya planu zakhodiv shchodo yiyi realizatsiyi (On approval of the Concept of development of the digital economy and society of Ukraine for 2018-2020 and approval of the action plan for its implementation), Order of the Cabinet of Ministers of Ukraine, 17 Jan 2018 No 67-p.

Verkhovna Rada of Ukraine. https://zakon.rada.gov.ua/laws/show/67-2018p/ed20180117\#n23. Accessed 25 Jan 2021

24. Digital Competitiveness Ranking 2019. IMD World Competitiveness center. 2019. 179 p. https://www.imd.org/wcc/world-competitivenesscenter-rankings/world-digital-competitivenessrankings-2019. Accessed 25 Jan 2021

25. Global Connectivity Index. Huawei Technologies CO., LTD. 2019. 53 p. https://www.huawei.com/ minisite/gci/assets/files/gci_2019_whitepaper_en.pd $\mathrm{f} ? \mathrm{v}=20191217 \mathrm{v} 2$. Accessed 25 Jan 2021

26. Global Innovation Index 2019: Ukraine. 9 p. https://www.globalinnovationindex.org/analysiseconomy. Accessed 25 Jan 2021

27. K. Schwab (ed.), The Global Competitiveness Report 2019 (World Economic Forum, Switzerland, 2019). $666 \mathrm{p}$. http://www3.weforum.org/docs/WEF_TheGlobalCo mpetitivenessReport2019.pdf. Accessed 25 Jan 2021

28. X. Li, C.A. Wang, The technology and economic determinants of cryptocurrency exchange rates: The case of Bitcoin. Decision Support Systems. 95, 4960 (2016). https://www.sciencedirect.com/science/ 
article/pii/S0167923616302111_.Accessed 25 Jan 2021

29. Cryptocurrency prices. BitInfoCharts. https://bitinfocharts.com/cryptocurrency-prices. Accessed 25 Jan 2021

30. Pro virtual'ni aktyvy (On virtual assets), Law of Ukraine: project, No 3637. Verkhovna Rada of Ukraine. https://w1.c1.rada.gov.ua/pls/zweb2/webproc4_1?pf $3511=69110$. Accessed 25 Jan 2021

31. Revenues from the artificial intelligence market worldwide from 2016 to 2025. Statista. https://www.statista.com/statistics/607716/worldwid e-artificial-intelligence-market-revenues. Accessed 25 Jan 2021

32. Pro skhvalennya Kontseptsiyi rozvytku shtuchnoho intelektu v Ukrayini (On approval of the Concept of development of artificial intelligence in Ukraine), Order of the Cabinet of Ministers of Ukraine, 02 Dec 2020 No 1556-p. Verkhovna Rada of Ukraine. https://zakon.rada.gov.ua/laws/show/1556-2020\%D1\%80\#Text. Accessed 25 Jan 2021

33. S. Tsyhanov, V. Apalkova, Rozvytok shtuchnoho intelektu: evolyutsiyni protsesy na mizhnarodnomu finansovomu rynku (Development of artificial intelligence: evolutional processes in the international financial market). Finansy Ukrayiny. 8 (2018), http://finukr.org.ua/docs/FU_18 08 020_uk.pdf. Accessed 25 Jan 2021

34. Azulay D. Artificial intelligence in finance - a comprehensive overview. Business intelligence and analytics. Emerj. 24 Dec 2019. https://emerj.com/aisector-overviews/artificial-intelligence-in-finance-acomprehensive-overview. Accessed 25 Jan 2021 